\title{
Nitrogen Fixation and Resorption Efficiency Differences Among Twelve Upland and Lowland Switchgrass Cultivars
}

\author{
Sarah S. Roley, ${ }^{1,2, \dagger}$ Tayler C. Ulbrich, ${ }^{2,3}$ and G. Philip Robertson ${ }^{1,2,4}$ \\ ${ }^{1}$ Great Lakes Bioenergy Research Center, Michigan State University, East Lansing, MI \\ ${ }^{2}$ W. K. Kellogg Biological Station, Michigan State University, Hickory Corners, MI \\ ${ }^{3}$ Department of Integrative Biology, Michigan State University, East Lansing, MI \\ ${ }^{4}$ Department of Plant, Soil and Microbial Sciences, Michigan State University, East Lansing, MI
}

Accepted for publication 23 May 2020.

\section{ABSTRACT}

In nitrogen (N)-limited terrestrial ecosystems, plants employ various strategies to acquire and conserve $\mathrm{N}$, including translocation of $\mathrm{N}$ in perennial tissues and stimulation of $\mathrm{N}$ fixation in roots and soils. Switchgrass (Panicum virgatum) is a genotypically and phenotypically diverse perennial grass with two distinct ecotypes (lowland and upland) and numerous genotypes. It grows well in low-N soils, likely because of its ability to translocate $\mathrm{N}$ and to associate with $\mathrm{N}$-fixing microbes, but little is known about variation in these traits among cultivars or even ecotypes. We measured $\mathrm{N}$ translocation, $\mathrm{N}$ fixation potential in roots and soils, soil net $\mathrm{N}$ mineralization, soil net nitrification, and biomass yields in 12 switchgrass cultivars grown in a replicated block experiment in southwestern Michigan, United States. Lowland cultivars had higher yields, rates of $\mathrm{N}$ translocation, soil net $\mathrm{N}$ mineralization, and $\mathrm{N}$ fixation potentials on washed, nonsterile roots, while upland cultivars exhibited higher $\mathrm{N}$ fixation potentials in root-free soil. $\mathrm{N}$ resorption efficiencies averaged $53 \pm 5 \%$ ( \pm standard error) for lowland versus $29 \pm 3 \%$ for upland cultivars. Additionally, there were significant among-cultivar differences for all response variables except mineralization and nitrification, with differences likely explained by cultivar-specific physiologies and microbial communities. The ideal cultivar for biofuels is one that can maintain high yields with minimal fertilizer addition, and there appear to be several cultivars that meet these criteria. In addition, results suggest substantial $\mathrm{N}$ cycle differences among cultivars that might be exploited by breeders to create new or improved high-yielding, $\mathrm{N}$-conserving switchgrass lines.

Keywords: agriculture, cellulosic biofuel, ecosystems, lowland, nitrogen fixation, nitrogen mineralization, nitrogen resorption efficiency, nutrient cycling, soil ecology, upland
All organisms require large amounts of nitrogen $(\mathrm{N})$ and yet it is in short supply in most terrestrial ecosystems, including grasslands (LeBauer and Treseder 2008). In response, grasses possess several

${ }^{\dagger}$ Corresponding author: S. S. Roley; sarah.roley@wsu.edu

Current address of S. S. Roley: School of the Environment, Washington State University, Richland, WA 99354, U.S.A.

Funding: Support for this research was provided by the Great Lakes Bioenergy Research Center, United States Department of Energy, Office of Science, Office of Biological and Environmental Research (DE-SC0018409); the National Science Foundation Long-Term Ecological Research Directorate for Biological Sciences (1637653 and 1832042) and Division of Environmental Biology (1754212) programs; and by Michigan State University AgBioResearch.

The author(s) declare no conflict of interest.

(C) 2021 The American Phytopathological Society strategies for acquiring $\mathrm{N}$ from the environment. Perennial grasses invest in deep, extensive roots and form relationships with mycorrhizal fungi that help extract $\mathrm{N}$ from the soil (Schroeder-Moreno et al. 2012). Plant roots can stimulate $\mathrm{N}$ mineralization, making soil organic N more available (Meier et al. 2017; Murphy et al. 2015), and can receive fixed $\mathrm{N}$ via an association with $\mathrm{N}$-fixing microbes (Bottomley and Myrold 2015). Perennial grasses translocate $\mathrm{N}$ from aboveground tissues to roots during senescence (Killingbeck 1996); this stored $\mathrm{N}$ decreases $\mathrm{N}$ acquisition needs in the following year.

The physicochemical template (including soil $\mathrm{N}, \mathrm{C}, \mathrm{pH}$, and moisture) constrains microbial $\mathrm{N}$ transformation rates (Brouzes et al. 1969; Chang and Knowles 1965; Dynarski and Houlton 2018; Liu et al. 2017; Perakis and Sinkhorn 2011; Roley et al. 2018), influences microbial community composition (Fierer and Jackson 2006; Jesus et al. 2016), and even alters interactions 
between microbes and plants. For example, plants may invest in microbial mutualisms when soil $\mathrm{N}$ is scarce but abandon them when $\mathrm{N}$ is abundant (Regus et al. 2017; Weese et al. 2015). Within a particular physicochemical template, plant species and genotypes employ different $\mathrm{N}$ acquisition and conservation strategies. For example, switchgrass (Panicum virgatum L.) cultivars grown in the same soil translocate N (Yang and Udvardi 2018; Yang et al. 2009) and appear to fix $\mathrm{N}$ at different rates (Rodrigues et al. 2017). It is unclear, however, how cultivars compare across multiple $\mathrm{N}$ acquisition and conservation strategies. Are there trade-offs? Is a cultivar with high translocation, for example, less successful at stimulating $\mathrm{N}$ fixation? Or are some cultivars more successful at $\mathrm{N}$ acquisition?

Switchgrass employs a number of strategies to obtain and conserve $\mathrm{N}$. It conserves $\mathrm{N}$ by translocating $\mathrm{N}$ to roots during senescence, which is retranslocated to growing aboveground tissues in the spring (Clark 1977; Heckathorn and Delucia 1996). Switchgrass also forms a mutualism with mycorrhizal fungi (Schroeder-Moreno et al. 2012) and obtains $\mathrm{N}$ from free-living diazotrophic bacteria in its rhizosphere in both laboratory (Morris et al. 1985; Tjepkema 1975) and field (Roley et al. 2019) settings. There are cultivar-level differences in switchgrass rhizosphere microbial communities, possibly as a result of differences in root exudation rates (Adkins et al. 2016; Revillini et al. 2019; Rodrigues et al. 2017; Roosendaal et al. 2016; Singer et al. 2019). However, mycorrhizal communities do not appear to differ among cultivars (Emery et al. 2018); therefore, variation in bacterial communities, rather than differences in fungal communities, may underlie variation in cultivars' $\mathrm{N}$ cycling. Such differences in microbial community composition, along with differences in phenological and physiological characteristics, may influence soil $\mathrm{N}$ cycling beneath switchgrass.

Switchgrass has wide genotypic and phenotypic variation, as manifested by its large geographic range: from northern Mexico to southern Canada and from dry and hot environments to cold and wet environments (Casler 2012; Lowry et al. 2014). This variation is categorized into two ecotypes (upland and lowland) that are differentiated by molecular and habitat traits. Upland genotypes evolved in drier, upland habitats and are typically found in northern climate zones, whereas lowland genotypes evolved in wetter, riparian areas and are typically found at lower latitudes (Lowry et al. 2014).

Because of the wide range of variability in switchgrass genotypes, there is an opportunity to choose cultivars for bioenergy (Mitchell et al. 2012) that are economically and environmentally sustainable: high-yielding, yet requiring minimal $\mathrm{N}$ fertilizer inputs. Understanding the $\mathrm{N}$ acquisition strategies of different cultivars will allow us to better predict which will do well in low-N environments. We address here the following questions: Does $\mathrm{N}$ acquisition and conservation differ by switchgrass cultivar? Do cultivars influence soil $\mathrm{N}$ cycling?

\section{MATERIALS AND METHODS}

Site description. We addressed our questions in the Switchgrass Variety Experiment (https://lter.kbs.msu.edu/research/long-termexperiments/glbrc-switchgrass-variety-experiment/), located at the Kellogg Biological Station (KBS) Long-Term Ecological Research site and part of the Great Lakes Bioenergy Research Center $\left(42^{\circ} 23^{\prime} \mathrm{N}, 85^{\circ} 22^{\prime} \mathrm{W}\right.$, elevation $284 \mathrm{~m}$ above sea level) in Hickory Corners, Michigan, United States. Soils at the site are Alfisol loams (Kalamazoo series Typic Hapludalfs), formed from glacial outwash with intermixed loess (Crum and Collins 1995; Luehmann et al. 2016). Prior to switchgrass establishment, the field was in rotational crops, including alfalfa, soybean, and maize. Climate at KBS is humid continental; mean annual air temperature is $10.1^{\circ} \mathrm{C}$, with an average of $-4.1^{\circ} \mathrm{C}$ in January and $22.8^{\circ} \mathrm{C}$ in July, and a mean total annual precipitation of $1,027 \mathrm{~mm}$, with approximately half falling as snow (1981 to 2010). Precipitation in the 2016 growing season (April to September) was $573 \mathrm{~mm}$ (KBS LTER Data Catalog 2019); the 27-year average is $614 \mathrm{~mm}$ (Michigan State Climatologist's Office 2019).

The Switchgrass Variety Experiment included 12 switchgrass cultivars in a randomized block design, with each cultivar replicated four times. Each block had 12 plots ( 4.6 by $12.2 \mathrm{~m}$ each), with each plot growing 1 of 12 cultivars. Switchgrass cultivars included four lowland (Alamo, Kanlow, EG 1101, and EG 1102) and eight upland (Southlow, Cave-in-Rock, Trailblazer, Blackwell, Dacotah, EG 2102, NE28, and Shelter) cultivars. Ten of the treatments were seeded in 2009, with two treatments (Shelter and EG 2102) planted in 2010. We completed all sampling in 2016, at which time all cultivars were well established.

After the first growing season, the plots were fertilized annually with $\mathrm{N}$ at $78 \mathrm{~kg} \mathrm{ha}^{-1}$ year $^{-1}$ applied as urea in the early growing season (usually May). Starting in 2010, the plots were harvested annually postsenescence (usually in October). During harvest, all aboveground biomass $>10 \mathrm{~cm}$ in height was removed from the plot with commercial forage harvest equipment. Additional details appear in Stahlheber et al. (in press).

Soil sampling. To normalize for phenological variability among different cultivars, we sampled each plot when the plants were flowering, rather than all on the same date. Sample dates were 28 June for Blackwell and Dacotah; 11 July for Shelter, EG 2102, and EG 1101; 18 July for Southlow, Cave-in-Rock, Trailblazer, and NE28; and 25 July for Alamo, Kanlow, and EG 1102. We chose to sample by phenology because growth stage influences the microbial $\alpha$ - and $\beta$-diversity within a cultivar (Rodrigues et al. 2017), and we wanted differences to reflect cultivars rather than growth stage. However, by sampling on different dates, we risked sampling under different soil conditions, most notably soil moisture, which complicates cultivar comparisons. We examined soil moisture through time and found that the minor changes in soil moisture did not influence any of the $\mathrm{N}$ cycling processes (see Results for details). Soil nitrate $\left(\mathrm{NO}_{3}^{-}\right)$concentration did change over sampling date; therefore, we included it as a covariate in all of our models (see Statistical Analysis, below) and, thus, are able to separate the effects of changes in soil $\mathrm{NO}_{3}^{-}$from the effects of cultivars and ecotypes.

We sampled three locations within each plot. At each location, we removed three 20-cm-depth soil cores with a 2-cm-diameter Oakfield push corer and composited the three samples by plot. We pushed the corer into the plant rhizosphere at a $45^{\circ}$ angle in order to sample directly beneath plants. The cores are likely a combination of rhizosphere and bulk soil but dominated by rhizosphere soil. Hereafter, "soil" refers to this combination of rhizosphere and bulk soil.

In the lab, we homogenized the soils by passing them through a 4$\mathrm{mm}$ sieve. We picked out all visible roots and washed them with unchlorinated ground water until they were free of visible soil particles. All root measurements were completed on washed, nonsterile roots, while all soil measurements were on root-free soil. After sieving, we placed roots and soil in a refrigerator $\left(4^{\circ} \mathrm{C}\right)$ until measurements began, within 3 days of collection. Immediately after sieving, we measured gravimetric soil moisture by drying a small sample in a $60^{\circ} \mathrm{C}$ drying oven for 2 days and measuring the change in water content.

Plant sampling. We sampled plant leaves twice in each cultivar: during flowering and again after senescence but before harvest. The date of sampling varied among cultivars, because they reached flowering and senescence on different dates (see Soil Sampling, above). We chose three plants in each plot and we retrieved three leaves from each plant by clipping at the base of the leaf with a 
scissors. We chose mature leaves that appeared healthy and free from insect or pathogen damage. This amount of subsampling is adequate for estimating $\mathrm{N}$ concentration in switchgrass leaves (Jach-Smith and Jackson 2015; Yang et al. 2009).

Soil and root $\mathbf{N}$ fixation potential. We measured $\mathbf{N}$ fixation potential with in vitro ${ }^{15} \mathrm{~N}_{2}$ incubations of washed, nonsterile roots and root-free, bulk plus rhizosphere switchgrass soil. For soils, we weighed $5 \mathrm{~g}$ into a gas-tight 12-ml Exetainer (Labco, Lampeter, Ceredigion, U.K.). After a 2-day equilibration period, we added enough $4 \%$ (wt/vol) glucose solution to raise the waterfilled pore space to $100 \%$ (Gupta et al. 2014; Roley et al. 2019) and to compensate for any evaporation that occurred during equilibration. For roots, we placed approximately $1 \mathrm{~g}$ of roots into a $12-\mathrm{ml}$ Exetainer and added $0.2 \mathrm{ml}$ of $4 \%$ glucose solution to replace moisture lost to evaporation and to relieve carbon (C) demands created by severing roots from the plant. The addition of glucose alleviates C limitation but also usually increases $\mathrm{N}$ fixation rates (Roley et al. 2018; Smercina et al. 2019b), thus making these measurements of $\mathrm{N}$ fixation potential, rather than of $\mathrm{N}$ fixation per se.

We sealed the Exetainers by adding caps with rubber septa. Using a needle attached to a syringe, we removed $4 \mathrm{ml}$ of headspace and then replaced it with $4.2 \mathrm{ml}$ of either ${ }^{15} \mathrm{~N}_{2}$ or unenriched $\mathrm{N}_{2}$ (controls). We placed the Exetainers in the dark at room temperature for 7 days. After 7 days, we measured the headspace volume by water displacement, then dried the contents at $60^{\circ} \mathrm{C}$ for at least 2 days. We pulverized the soil or roots in a SPEX Shatterbox (Metuchen, NJ, U.S.A.) and then packed samples in tin capsules for isotopic analysis. All samples were analyzed at the University of California Davis Stable Isotope Laboratory (Davis, CA, U.S.A.).

We used the ${ }^{15} \mathrm{~N}$ content to calculate the $\mathrm{N}$ fixation rate. First, we calculated atom excess (AE) of soil or roots as the ${ }^{15} \mathrm{~N}$ content of the enriched vial minus the ${ }^{15} \mathrm{~N}$ content in the corresponding control vial. Next, we calculated fixation, in micrograms of $\mathrm{N}$ per vial per day, as

$$
N_{f i x}=\left(A E_{i} \times T N_{i}\right) /\left(A E_{a t m} \times t\right)
$$

where $\mathrm{AE}_{\mathrm{i}}$ is the ${ }^{15} \mathrm{~N} \mathrm{AE}$ in the root or soil, $\mathrm{TN}_{\mathrm{i}}$ is the total milligrams of $\mathrm{N}$ in the soil or root, and $t$ is time in days. We calculated $\mathrm{AE}_{\mathrm{atm}}$, which is the ${ }^{15} \mathrm{~N} \mathrm{AE}$ in the headspace of the vial, by dividing the volume of ${ }^{15} \mathrm{~N}_{2}$ added by the total $\mathrm{N}_{2}$ in the headspace, assuming atmospheric concentrations of $\mathrm{N}_{2}$. The $\mathrm{AE}_{\mathrm{atm}}$ calculations may be slight overestimates because they do not account for any denitrification (and, thus, higher ${ }^{14} \mathrm{~N}_{2}$ concentration) that occurs during the incubation. The result of an overestimate in $\mathrm{AE}_{\mathrm{atm}}$ is a lower $\mathrm{N}$ fixation rate. We then divided each rate by the dry mass of the material in the Exetainer, resulting in fixation expressed as micrograms of $\mathrm{N}$ per gram of root or soil per day.

Net $\mathbf{N}$ mineralization and nitrification. We assessed net potential mineralization rates with a 7-day incubation. We adjusted soils to $65 \%$ water-filled pore space (Jarrell et al. 1999) and then weighed $10 \mathrm{~g}$ of soil into each of six specimen cups. We immediately extracted $\mathrm{NO}_{3}^{-}$and ammonium $\left(\mathrm{NH}_{4}^{+}\right)$from three cups and placed the other three in a dark environmental chamber at $22^{\circ} \mathrm{C}$. After 7 days, we removed the cups from the environmental chamber and extracted $\mathrm{NO}_{3}^{-}$and $\mathrm{NH}_{4}^{+}$(Robertson et al. 1999).

We extracted inorganic $\mathrm{N}$ by adding $100 \mathrm{ml}$ of $1 \mathrm{M} \mathrm{KCl}$ to each cup, shaking vigorously for $1 \mathrm{~min}$, resting on a lab bench for $24 \mathrm{~h}$, then reshaking and filtering the supernatant (Robertson et al. 1999). We froze sample extracts until analysis. We measured $\mathrm{NO}_{3}^{-}$via cadmium reduction and $\mathrm{NH}_{4}^{+}$via the phenolhypochlorite method on a Lachat QC 8500 (Hach, Loveland Park, CO, U.S.A.).
We calculated net mineralization as the net change in inorganic $\mathrm{N}$ over the course of the incubation, using the following equation:

$$
N_{M}=\left[\left(N I T_{T 7}+A M M_{T 7}\right)-\left(N I T_{T 0}+A M M_{T 0}\right)\right] / 7 \text { days }
$$

where $\mathrm{N}_{\mathrm{M}}=$ net $\mathrm{N}$ mineralization, $\mathrm{NIT}_{\mathrm{T} 7}$ is the $\mathrm{NO}_{3}^{-}$concentration at day $7, \mathrm{AMM}_{\mathrm{T} 7}$ is the $\mathrm{NH}_{4}^{+}$concentration at day 7, $\mathrm{NIT}_{\mathrm{T} 0}$ is the $\mathrm{NO}_{3}^{-}$concentration at the beginning of the incubation, and $\mathrm{AMM}_{\mathrm{T} 0}$ is the $\mathrm{NH}_{4}^{+}$concentration at the beginning of the incubation.

Net nitrification $\left(\mathrm{N}_{\mathrm{N}}\right)$ is the accumulation of $\mathrm{NO}_{3}^{-}$, which we calculated as follows:

$$
N_{N}=\left[\left(N I T_{T 7}-N I T_{T 0}\right) / 7\right. \text { days }
$$

$\mathbf{N}$ translocation. To calculate $\mathrm{N}$ translocation, we measured the $\mathrm{N}$ content of leaves at peak biomass and again after senescence (see Soil Sampling, above, for sampling dates). We dried leaf samples at $60^{\circ} \mathrm{C}$ for at least 2 days. Then, we pulverized the leaves into a fine powder and packed it into tin capsules. We measured the $\mathrm{C}$ and $\mathrm{N}$ concentration via combustion on a Costech Elemental Analyzer (Valencia, CA, U.S.A.). We used two different metrics to assess $\mathrm{N}$ translocation: $\mathrm{N}$ resorption proficiency and $\mathrm{N}$ resorption efficiency (Killingbeck 1996). N resorption proficiency is the $\mathrm{N}$ concentration at the end of the growing season (percent $\mathrm{N}$ after senescence); lower proficiency indicates higher translocation. $\mathrm{N}$ resorption efficiency is the relative proportion of the leaf $\mathrm{N}$ pool that is resorbed during senescence; higher efficiency indicates higher translocation. Resorption efficiency is calculated as

$$
N_{\text {resorption }}=1-\left\{0.713 \times\left([N]_{\text {senensced leaf }} /[N]_{\text {green leaf }}\right)\right\} \times 100
$$

where 0.713 is the mass loss correction factor for grasses, which accounts for the leaf mass loss with senescence (Vergutz et al. 2012).

Statistical analysis. To determine yield differences, we completed an analysis of variance (ANOVA), followed by Tukey's honestly significant difference (HSD) to analyze pairwise differences. We completed a separate analysis for ecotype and cultivar.

To address whether ecotype or cultivar influenced $\mathrm{N}$ cycling rates, we performed an analysis of covariance, with soil $\mathrm{NO}_{3}^{-}$ concentration as the covariate. We fit the model with general least squares, using the nlme package in $\mathrm{R}$, version 3.4.3 (R Core Team 2017). We checked for normality and homoscedasticity of the residuals; if the data did not meet assumptions, we employed alternative variance structures that did not assume normality and homoscedasticity. We analyzed cultivar and ecotype separately, because models that included both (i.e., a nested structure) did not converge. We included soil $\mathrm{NO}_{3}^{-}$concentration as a covariate because soil $\mathrm{N}$ is a well-known driver of fixation rates and because there were block-specific and date-specific differences in soil $\mathrm{NO}_{3}^{-}$ concentration. Although we had a variety of inorganic $\mathrm{N}$ measurements $\left(\mathrm{NO}_{3}^{-}, \mathrm{NH}_{4}^{+}\right.$, total inorganic $\mathrm{N}$, and mineralization), we used $\mathrm{NO}_{3}^{-}$because it had the highest correlation with each of the response variables. We completed the same analysis for each of the $\mathrm{N}$ cycling response variables: potential soil $\mathrm{N}$ fixation, potential root $\mathrm{N}$ fixation, net $\mathrm{N}$ mineralization, net nitrification, $\mathrm{N}$ resorption proficiency, and $\mathrm{N}$ resorption efficiency.

\section{RESULTS}

Effect of sampling date. Water-filled pore space changed over the course of the sampling, from a low of $56.4 \pm 1.2 \%$ ( \pm standard error [SE]) on 28 June to a high of $62.5 \pm 1.9 \%$ on 18 July 
(corresponding gravimetric soil moisture was 14.8 and $16.1 \%$, respectively). Those two dates are significantly different from one another (ANOVA with Tukey's HSD, $P=0.003$ ). Despite this, soil moisture was not a significant predictor of any of the soil process measurements $(P>0.6$ for all). We conclude that a shift from 56 to $63 \%$ water-filled pore space, while statistically significant, is not biologically significant.

Soil $\mathrm{NO}_{3}^{-}$concentration also changed over the course of our sampling, from a low of $0.70 \pm 0.22 \mu \mathrm{g} \mathrm{N}$ per gram of soil $\left(\mathrm{g} \mathrm{soil}^{-1}\right)$ on 11 July to $1.46 \pm 0.55 \mu \mathrm{g} \mathrm{N} \mathrm{g} \mathrm{soil}{ }^{-1}$ on $18 \mathrm{July}$. This difference is statistically significant (ANOVA with Tukey's HSD, $P=0.04$ ), and we account for differences in soil $\mathrm{NO}_{3}^{-}$concentration by including it as a covariate in all models.

Yield. Yields in 2016 varied dramatically by cultivar, ranging from $3.92 \pm 1.06(\mathrm{SE}) \mathrm{Mg} \mathrm{ha}^{-1}$ for Dacotah to $11.04 \pm 0.69 \mathrm{Mg} \mathrm{ha}^{-1}$ for EG $1102(P<0.00001)$. Pairwise comparisons revealed that yields for Dacotah were lower than most cultivars, while yields for Kanlow and EG 1102 were higher than most (Fig. 1). Yields were

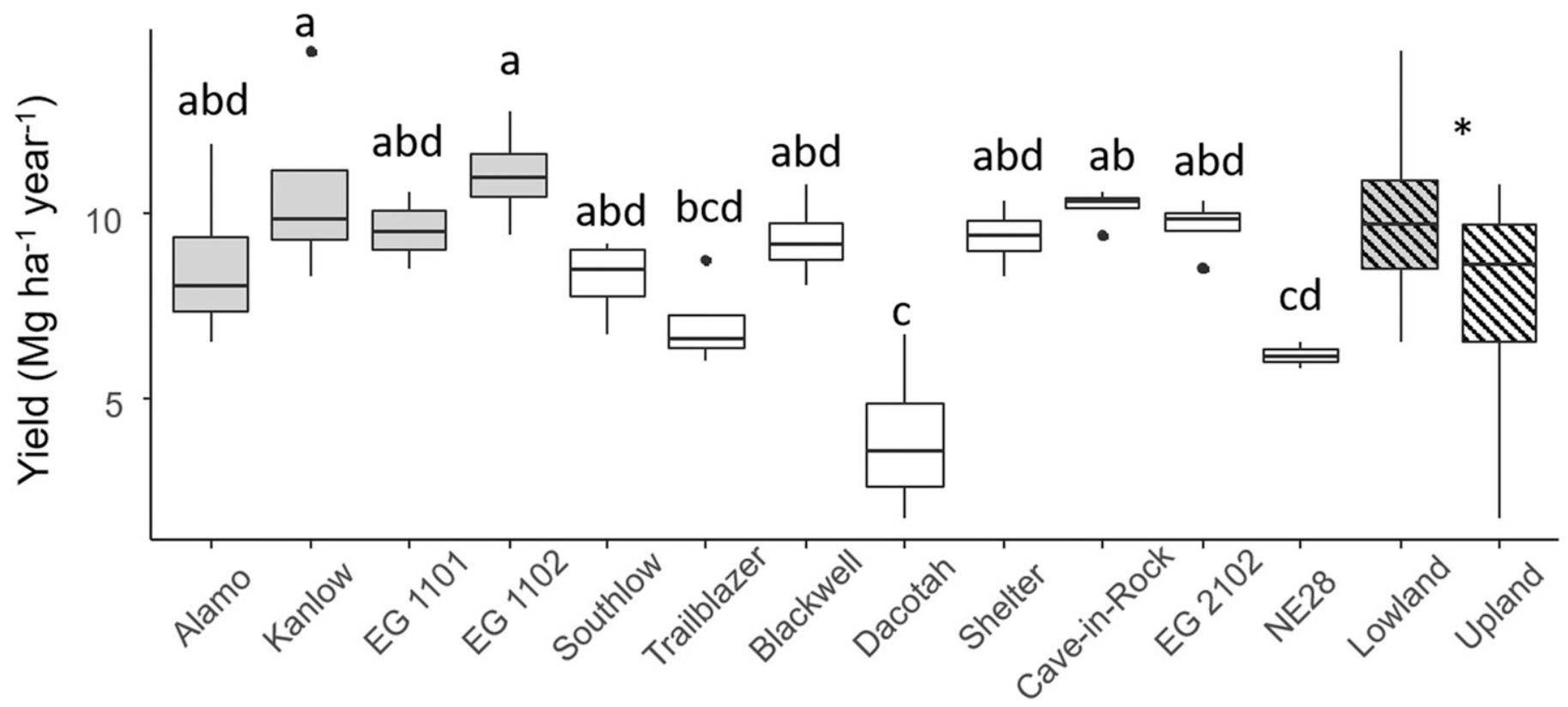

Fig. 1. Biomass yield of 12 cultivars grown in a replicated block experiment and harvested in the fall. Lowland cultivars are shaded gray and upland cultivars are in white. Upper and lower hinges correspond to the first and third quartiles, respectively; the line corresponds to the median; and the whiskers correspond to the largest value $<1.5$ times the interquartile range. Dots are plotted as values $>1.5 \times$ the interquartile range. Letters indicate differences among cultivars and the asterisk indicates differences between ecotypes.
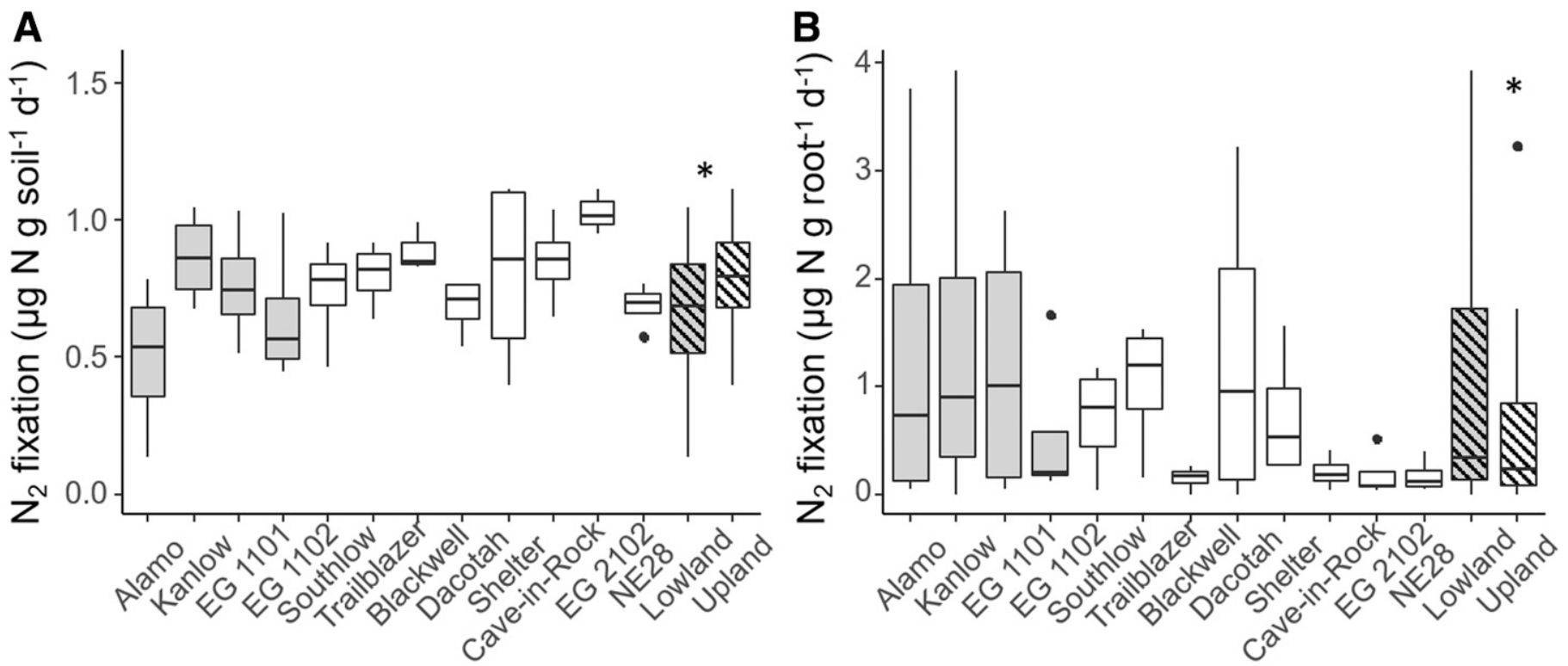

Fig. 2. Nitrogen fixation potentials in A, bulk + rhizosphere soil and B, roots of 12 switchgrass cultivars. Lowland cultivars are shaded gray and upland cultivars are in white. Upper and lower hinges correspond to the first and third quartiles, respectively; the line corresponds to the median; and the whiskers correspond to the largest value $<1.5$ times the interquartile range. Dots are plotted as values $>1.5 \times$ the interquartile range. The asterisk indicates differences between ecotypes. 
significantly higher for lowland ecotypes, which averaged $9.95 \pm$ 0.5 (SE) $\mathrm{Mg} \mathrm{ha}^{-1}$, compared with $7.97 \pm 0.40 \mathrm{Mg} \mathrm{ha}^{-1}$ in upland ecotypes $(P=0.005)$ (Fig. 1). The yield differences were significant, even with the two lowest-yielding upland cultivars (Dacotah and NE28) removed from the analysis $(P=0.014)$. Yields from upland ecotypes were also more variable, with some upland cultivars producing relatively low yields (e.g., Dacotah and NE28, $6.16 \pm$ $0.14 \mathrm{Mg} \mathrm{ha}^{-1}$ ) and other upland cultivars approaching the highest yields (e.g., Cave-in-Rock, $10.14 \pm 0.25 \mathrm{Mg} \mathrm{ha}^{-1}$; Shelter, $9.36 \pm$ $0.42 \mathrm{Mg} \mathrm{ha}^{-1}$; and Blackwell, $9.30 \pm 0.56 \mathrm{Mg} \mathrm{ha}^{-1}$ ).

$\mathbf{N}$ fixation potential. Soil $\mathrm{N}$ fixation potentials varied with cultivar $(P=0.027)$ and ranged from rates of $0.50 \pm 0.14(\mathrm{SE}) \mu \mathrm{g}$ $\mathrm{N} \mathrm{g} \mathrm{soil}{ }^{-1}$ day $^{-1}$ in Alamo to $1.31 \pm 0.27 \mu \mathrm{g} \mathrm{N} \mathrm{g} \mathrm{soil}^{-1}$ day $^{-1}$ in EG 2102 (Fig. 2A). Soil $\mathrm{N}$ fixation potentials declined with soil $\mathrm{NO}_{3}^{-}$ concentration $(P=0.036$, coefficient $=-0.13)$ and were higher in upland ecotypes, where rates averaged $0.87 \pm 0.06 \mu \mathrm{g} \mathrm{g}$ soil $^{-1}$ day $^{-1}$ compared with lowland ecotypes with an average rates of $0.69 \pm 0.06 \mu \mathrm{g} \mathrm{N} \mathrm{g} \mathrm{soil}{ }^{-1} \mathrm{day}^{-1}(P=0.032)$. Although ecotypes differed overall, individual cultivars did not always cluster neatly by ecotype. For example, although lowland ecotypes had lower soil $\mathrm{N}$ fixation potentials on average, one lowland cultivar (Kanlow) had one of the higher soil $\mathrm{N}$ fixation potentials. The response of soil $\mathrm{N}$ fixation potential to soil $\mathrm{NO}_{3}^{-}$varied by cultivar, with Blackwell $(P=$ $0.04)$ and EG $2102(P=0.0003)$ driving most of this variation ( $\mathrm{NO}_{3}^{-}$-cultivar interaction, $P=0.04$ and $P=0.07$, respectively). Other cultivars had weak or nonsignificant effects.

Root $\mathrm{N}$ fixation potentials ranged from rates of $0.2 \pm 0.08$ (SE) $\mu \mathrm{g}$ $\mathrm{N} \mathrm{g} \mathrm{root}{ }^{-1}$ day $^{-1}$ in Cave-in-Rock to $1.44 \pm 0.88 \mu \mathrm{g} \mathrm{N} \mathrm{g} \mathrm{root}^{-1}$ day $^{-1}$ in Kanlow (Fig. 2B). In contrast to soil $\mathrm{N}$ fixation, root $\mathrm{N}$ fixation potentials clustered more clearly by ecotype, with lowland cultivars generally having higher $\mathrm{N}$ fixation potentials $(P<0.0001)$. There were no significant among-cultivar differences $(P=0.14)$. Root potential $\mathrm{N}$ fixation declined with soil $\mathrm{NO}_{3}^{-}$concentration $(P<$ 0.0001 ), and ecotype had a differential influence on $\mathrm{N}$ fixation (ecotype- $\mathrm{NO}_{3}^{-}$interaction, $P<0.0001$ ). In lowland cultivars, root fixation potentials declined with soil $\mathrm{NO}_{3}^{-}$concentration (fixation $=-2.67 \times$ soil $\mathrm{NO}_{3}^{-}=+3.56, r^{2}=0.54, P=0.0007$ ) but, in upland cultivars, root $\mathrm{N}$ fixation rates showed no relationship with soil $\mathrm{NO}_{3}^{-}$concentration when all upland cultivars were pooled together $\left(r^{2}<0.01, P=0.7\right)$, probably because there was more variability in $\mathrm{NO}_{3}^{-}$concentrations in soils beneath upland cultivars. Individual cultivars varied in their response to soil $\mathrm{NO}_{3}^{-}$concentrations $\left(\mathrm{NO}_{3}^{-}\right.$-cultivar interaction, $\left.P=0.015\right)$, with some individual upland cultivars (Cave-in-Rock, Shelter, Southlow, and Trailblazer) showing a distinct $\mathrm{NO}_{3}^{-}$response $(P<0.05$ for those listed).

$\mathrm{N}$ translocation. $\mathrm{N}$ resorption proficiencies ranged from $0.47 \pm$ $0.03 \%$ (SE) in EG 1102 to $1.86 \pm 0.10 \%$ in Dacotah (Fig. 3A). Proficiency varied with cultivar $(P<0.00001)$ (Fig. 3A) and increased with soil inorganic $\mathrm{N}$ concentration (coefficient $=0.094$, $P=0.018$ ). This effect was consistent across cultivars; the $\mathrm{NO}_{3}^{-}$-cultivar interaction was not significant $(P=0.33)$. N proficiencies were lower in the lowland cultivars $(P<0.0001)$, with lowland cultivars averaging $0.79 \pm 0.11 \%$ and upland cultivars averaging $1.35 \pm 0.05 \%$ (Fig. 3A); however, when comparing between ecotypes, soil $\mathrm{N}$ (expressed as $\mathrm{NO}_{3}^{-}$, inorganic $\mathrm{N}$, or $\mathrm{NH}_{4}^{+}$) was no longer a significant covariate $(P=0.48)$.

$\mathrm{N}$ resorption efficiencies ranged from $34.7 \pm 7.5 \%(\mathrm{SE})$ in Trailblazer to $78.4 \pm 1.3 \%$ (SE) in EG 1102 (Fig. 3B). Resorption efficiencies were generally higher in the lowland cultivars, which averaged $66.6 \pm 7.6 \%$, compared with $48.5 \pm 6.0 \%$ in the upland cultivars $(P<0.0001)$, although lowland EG 1101 had a resorption efficiency more characteristic of the upland cultivars (Fig. 3B). Efficiency was also strongly influenced by cultivar, with a small block effect (cultivar $P<0.00001$; block $P<0.012$ ). The block effect was consistent among cultivars; the interaction term was not significant $(P>0.2)$.

The two $\mathrm{N}$ translocation metrics were generally in agreement. Cultivars with the lowest leaf $\mathrm{N}$ at senescence (proficiency) were also resorbing the largest proportion of their leaf $\mathrm{N}$ (efficiency).

$\mathbf{N}$ mineralization and nitrification. Net $\mathrm{N}$ mineralization rates were generally negative; that is, more soil inorganic $\mathrm{N}$ was immobilized than produced. Rates were constrained to a narrow
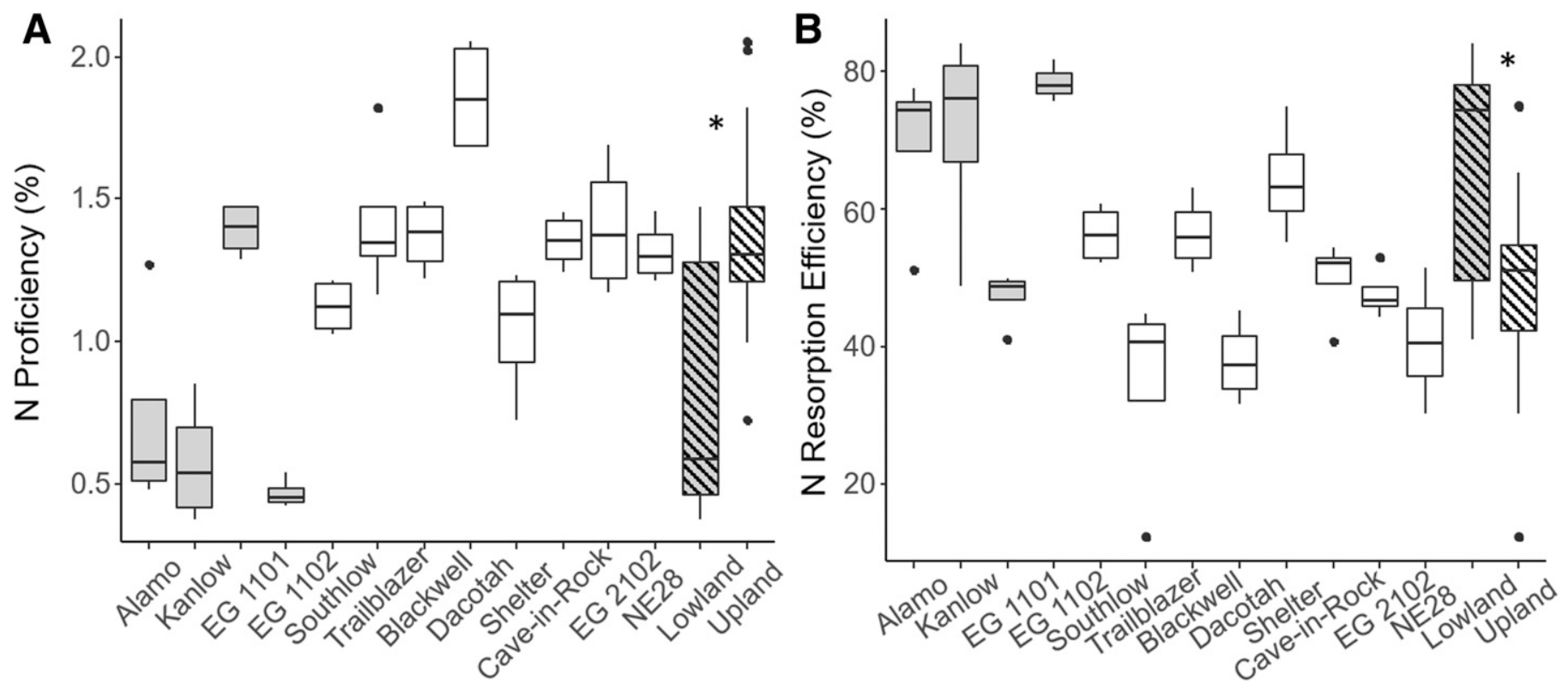

Fig. 3. A, Nitrogen proficiency and B, nitrogen resorption efficiency of 12 switchgrass cultivars. Lowland cultivars are shaded gray and upland cultivars are in white. Upper and lower hinges correspond to the first and third quartiles, respectively; the line corresponds to the median; and the whiskers correspond to the largest value $<1.5$ times the interquartile range. Dots are plotted as values $>1.5 \times$ the interquartile range. The asterisk indicates differences between ecotypes. 
range, from an average of $-0.44 \pm 0.15$ (SE) $\mathrm{mg} \mathrm{N} \mathrm{kg} \mathrm{soil}^{-1}$ day $^{-1}$ in Southlow to $0.33 \pm 0.54 \mathrm{mg} \mathrm{N} \mathrm{kg} \mathrm{soil}^{-1}$ day $^{-1}$ in EG 1102 (Fig. 4A). Individual replicates had $\mathrm{N}$ from $-0.77 \mathrm{mg} \mathrm{N} \mathrm{kg} \mathrm{soil}^{-1} \mathrm{day}^{-1}$ in a replicate of Southlow to $1.92 \mathrm{mg} \mathrm{N} \mathrm{kg} \mathrm{soil}^{-1} \mathrm{day}^{-1}$ in a replicate from EG 1102. EG 1102 was the only cultivar where the mean mineralization rate was $>0$ but, even so, its median was $<0$ (Fig. 4A). Rates did not vary with cultivar $(P=0.46)$ but did increase with soil $\mathrm{NO}_{3}^{-}$concentration (coefficient $=0.191, P=0.0236$ ). Net $\mathrm{N}$ mineralization rates were slightly higher in lowland cultivars $(P=$ $0.04)$, with an average rate of $0.03 \pm 0.14 \mathrm{mg} \mathrm{N} \mathrm{kg} \mathrm{soil}^{-1} \mathrm{day}^{-1}$ in lowlands, compared with $-0.20 \pm 0.05 \mathrm{mg} \mathrm{N} \mathrm{kg} \mathrm{soil}^{-1}$ day $^{-1}$ in uplands. Soil microbial C:N ratios (calculated from data of T. C. Ulbrich, M. L. Friesen, S. S. Roley, L. K. Tiemann, and S. E. Evans [unpublished]) were significantly higher in uplands (ANOVA, $P=$ 0.0014 ), with an average of $7.68 \pm 0.43$, while lowland soil microbial C:N ratio averaged $5.68 \pm 0.39$.

Net nitrification rates were close to zero, with most replicates slightly greater than zero and some negative (Fig. 4B). Negative nitrification rates indicate net consumption of $\mathrm{NO}_{3}^{-}$(Fig. 4B). Rates ranged from $-0.28 \mathrm{mg} \mathrm{N} \mathrm{kg} \mathrm{soil}^{-1}$ day $^{-1}$ in a replicate of NE28 to $0.78 \mathrm{mg} \mathrm{N} \mathrm{kg} \mathrm{soil}{ }^{-1} \mathrm{day}^{-1}$ in a replicate of Blackwell, with an overall average rate of $0.13 \pm 0.03(\mathrm{SE}) \mathrm{mg} \mathrm{N} \mathrm{kg} \mathrm{soil}^{-1} \mathrm{day}^{-1}$. Nitrification rates increased linearly with soil inorganic $\mathrm{N}$ concentration $\left(r^{2}=0.21, P=0.0006\right)$ but neither cultivar nor ecotype influenced nitrification rates $(P>0.08$ for all).

\section{DISCUSSION}

Switchgrass lowland ecotypes had higher yields, N translocation, and root $\mathrm{N}$ fixation potentials, while upland ecotypes had higher soil $\mathrm{N}$ fixation potentials. But intraecotype variability was quite high, with rates varying by cultivar and individual cultivars not always following broad ecotype-level patterns. Variation among cultivars was likely due to a combination of factors, including cultivar-specific phenology, physiology, and microbial community composition. In contrast to variation in $\mathrm{N}$ fixation and $\mathrm{N}$ translocation, switchgrass cultivars and ecotypes had little effect on net mineralization and nitrification.

$\mathbf{N}$ translocation. Lowland ecotypes conserved more $\mathrm{N}$ in their tissues than upland ecotypes. They resorbed a higher proportion of plant $\mathrm{N}$ and reduced their aboveground tissue $\mathrm{N}$ concentrations to lower levels than did upland ecotypes. This pattern appears to be consistent across a wide range of switchgrass cultivars (Yang and Udvardi 2018; Yang et al. 2009). Upland ecotypes mostly originate from higher latitudes than the lowland ecotypes (Lowry et al. 2014) and, consequently, begin flowering and senescence earlier than lowland ecotypes (Yang and Udvardi 2018). Perhaps lowland ecotypes' ability to maintain growth for a longer period (even at high latitudes) is supported by their ability to store a greater proportion of their $\mathrm{N}$ in belowground tissues.

Switchgrass at our site had more $\mathrm{N}$ remaining in its tissues at senescence (i.e., higher proficiency) but had similar resorption efficiencies compared with a subset of the same cultivars grown in Oklahoma, United States (Yang et al. 2009). The patterns among ecotypes and cultivars (i.e., the rank of the cultivars) were generally consistent between the two sites. For example, Kanlow had the highest resorption efficiency at both KBS and in Oklahoma (of those measured at both sites; EG 1102 was not in Oklahoma). This suggests that, whereas the actual proficiency and resorption efficiencies are influenced by soil N (Jach-Smith and Jackson 2015) and climate (Ren et al. 2018) and possibly other site-specific factors, the effort devoted to resorbing $\mathrm{N}$ is inherent to each cultivar's physiology.

We found a weak but significant decline in $\mathrm{N}$ translocation with soil $\mathrm{N}$, when translocation was expressed as proficiency. We observed no effect of soil $\mathrm{N}$ on resorption efficiency. In other words, plants with more soil $\mathrm{N}$ available had more $\mathrm{N}$ in their leaves at senescence but translocated the same proportion of leaf $\mathrm{N}$ to their roots as plants growing in lower-N soil. This result is in contrast to results of Jach-Smith and Jackson (2015), who found that $\mathrm{N}$ fertilizer addition increased $\mathrm{N}$ translocation (i.e., decreased proficiency and increased efficiency) in the cultivar examined (Forestburg).
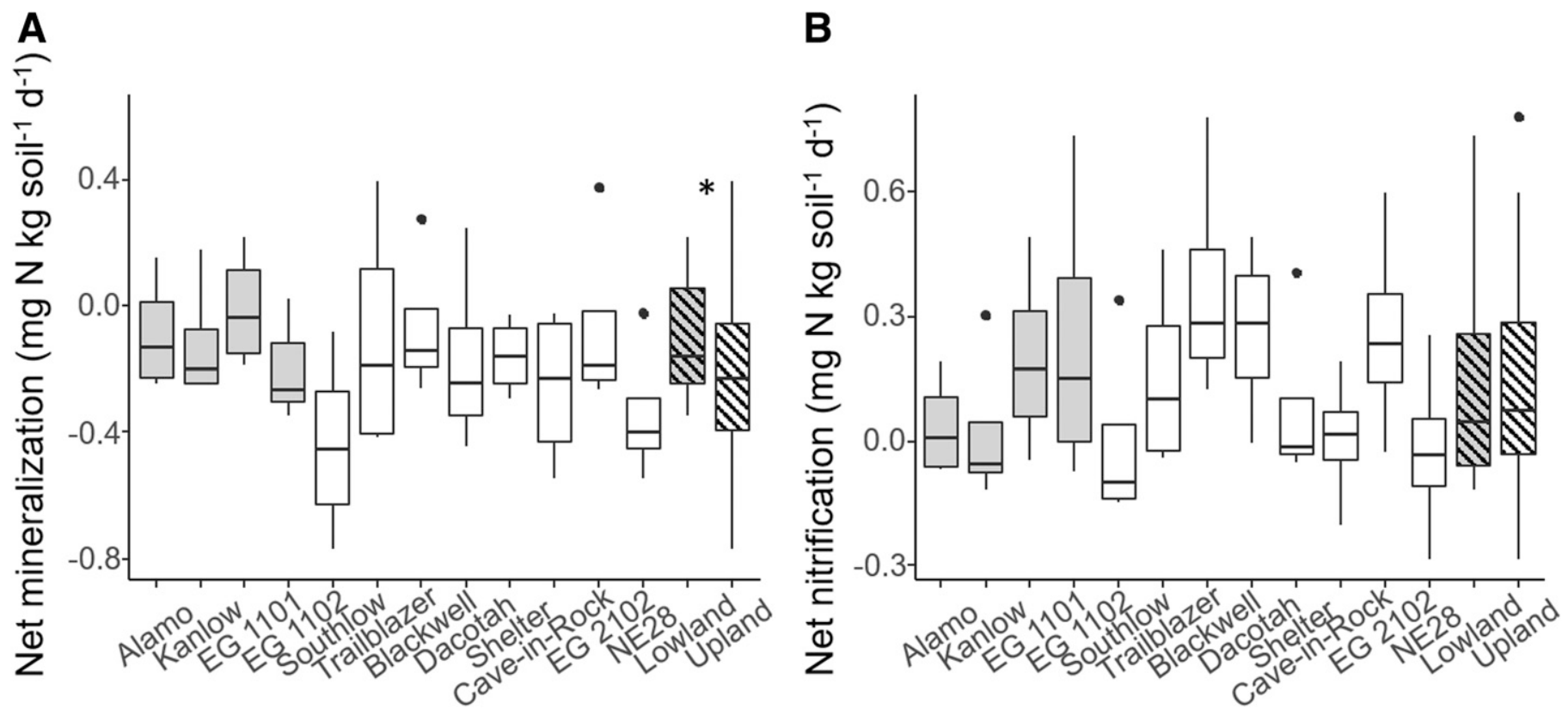

Fig. 4. A, Soil net mineralization rate and B, soil net nitrification rate in soils beneath 12 switchgrass cultivars. Lowland cultivars are shaded gray and upland cultivars are in white. Upper and lower hinges correspond to the first and third quartiles, respectively; the line corresponds to the median; and the whiskers correspond to the largest value $<1.5$ times the interquartile range. Dots are plotted as values $>1.5 \times$ the interquartile range. The asterisk indicates differences between ecotypes. 
They also manipulated soil $\mathrm{N}$ across a wider range than we observed, so perhaps the $\mathrm{N}$ response is context dependent.

Cultivar effects on potential $\mathbf{N}$ fixation. Both root and soil $\mathrm{N}$ fixation potential varied with cultivar and ecotype but did so in different ways. Upland ecotypes exhibited higher soil $\mathrm{N}$ fixation potential, while lowland ecotypes had higher and more variable root $\mathrm{N}$ fixation potential. Some cultivars that had high soil $\mathrm{N}$ fixation potentials had low root $\mathrm{N}$ fixation potentials, whereas other cultivars were consistently high or low. For example, Alamo had the secondhighest root $\mathrm{N}$ fixation potential but the lowest soil $\mathrm{N}$ fixation potential. Kanlow, on the other hand, had consistently high potentials (highest rate in roots, third-highest in soil) and NE28 had consistently low $\mathrm{N}$ fixation potential in both roots and soils (Table 1). These distinct soil versus root patterns may be related to factors that differentially influence root and soil microbes. Root microbes will be strongly influenced by root metabolites (endophytes) and exudates (rhizoplane microbes) as well as plantimposed gradients in soil chemistry (Bulgarelli et al. 2013; Reinhold-Hurek et al. 2015; Yu and Hochholdinger 2018), whereas soil microbes will be influenced by root exudates along with the full suite of physical, chemical, and biological interactions between roots and soil (Reinhold-Hurek et al. 2015).

Both root and soil $\mathrm{N}$ fixation are potentially important to the switchgrass $\mathrm{N}$ budget, although root $\mathrm{N}$ fixation is arguably a more direct path for $\mathrm{N}$ uptake than soil $\mathrm{N}$ fixation because of physical proximity to the plant. $\mathrm{N}$ fixation rates were also generally higher on root tissues than in soil, despite our use of a method that is optimized for soil and probably suboptimal for roots.

At the same time that we sampled for $\mathrm{N}$ cycling processes, we also sampled for root traits and microbial communities. Samples were taken on the same dates and from the same plants, using similar coring methods, albeit from separate, proximate soil cores. Those results are beyond the scope of this article and are reported elsewhere (T. C. Ulbrich, M. L. Friesen, S. S. Roley, L. K. Tiemann, and S. E. Evans, unpublished). Relevant to this article, Ulbrich and associates found that the abundance of putative $\mathrm{N}$ fixers, based on PICRUSt analysis (Langille et al. 2013), varied by cultivar but wasn't correlated with the $\mathrm{N}$ fixation rates reported in this article. Compared with soils, sterilized roots (i.e., largely endophyte communities) in these plots had greater relative abundance of the common N-fixing orders Burkholderiales and Rhizobiales (T. C. Ulbrich, M. L. Friesen, S. S. Roley, L. K. Tiemann, and S. E. Evans, unpublished), which could have contributed to the higher $\mathrm{N}$ fixation rates in roots; however, these are coarse taxonomic generalizations that should be studied in greater functional detail. Nevertheless, despite higher $\mathrm{N}$ fixation potentials in roots, soil encompasses more volume on an ecosystem basis and, thus, soil $\mathrm{N}$ fixation can contribute more overall to ecosystem $\mathrm{N}$ inputs (Roley et al. 2018).

The cultivar and ecotype differences in $\mathrm{N}$ fixation potential occurred independently of soil $\mathrm{N}$ and moisture content, suggesting two potential, interrelated mechanisms for these effects: (i) cultivarspecific microbiomes that differ in $\mathrm{N}$ fixation ability or (ii) cultivarspecific effects on soil $\mathrm{C}$ availability. Soil microbial community composition varied among switchgrass cultivars in our study plots (T. C. Ulbrich, M. L. Friesen, S. S. Roley, L. K. Tiemann, and S. E. Evans, unpublished), consistent with previous observations elsewhere (Revillini et al. 2019; Rodrigues et al. 2017; Roosendaal et al. 2016; Singer et al. 2019). The microbial communities beneath some cultivars were likely more adept at $\mathrm{N}$ fixation than others (i.e., they were able to fix more $\mathrm{N}$ ), although the mechanism remains unclear. $\mathrm{N}$ fixation rates tend to increase with diazotrophic richness and diversity (Hsu and Buckley 2009) but do not consistently increase with nifH abundance (Lindsay et al. 2010; Rocca et al. 2015; Rodrigues et al. 2017; Wang et al. 2018).

In our plots, the relative abundance of putative $\mathrm{N}$ fixers, determined via PICRUSt (Langille et al. 2013), did not correlate with soil N fixation potential (T. C. Ulbrich, M. L. Friesen, S. S. Roley, L. K. Tiemann, and S. E. Evans, unpublished). This lack of correlation is perhaps not surprising, given that nifH transcription occurs in a low proportion of soil taxa at any particular time (Bahulikar et al. 2014; Burgmann et al. 2005), as well as the challenge of extrapolating function from $16 \mathrm{~S}$ genes (Jovel et al. 2016). In addition, it may be that a few particularly active taxa drive $\mathrm{N}$ fixation rates, rather than fixer abundance or diversity (Gupta et al. 2014). Cultivars with high $\mathrm{N}$ fixation rates may harbor a more active diazotroph community such that nifH activity was higher, even if nifH abundance was not (Reed et al. 2010; Rodrigues et al. 2017).

$\mathrm{N}$ fixation is an energy-intensive process and so generally increases with C availability (Brouzes et al. 1969; Chang and

TABLE 1

Nitrogen (N) cycling means, standard errors, and relative rank by cultivar

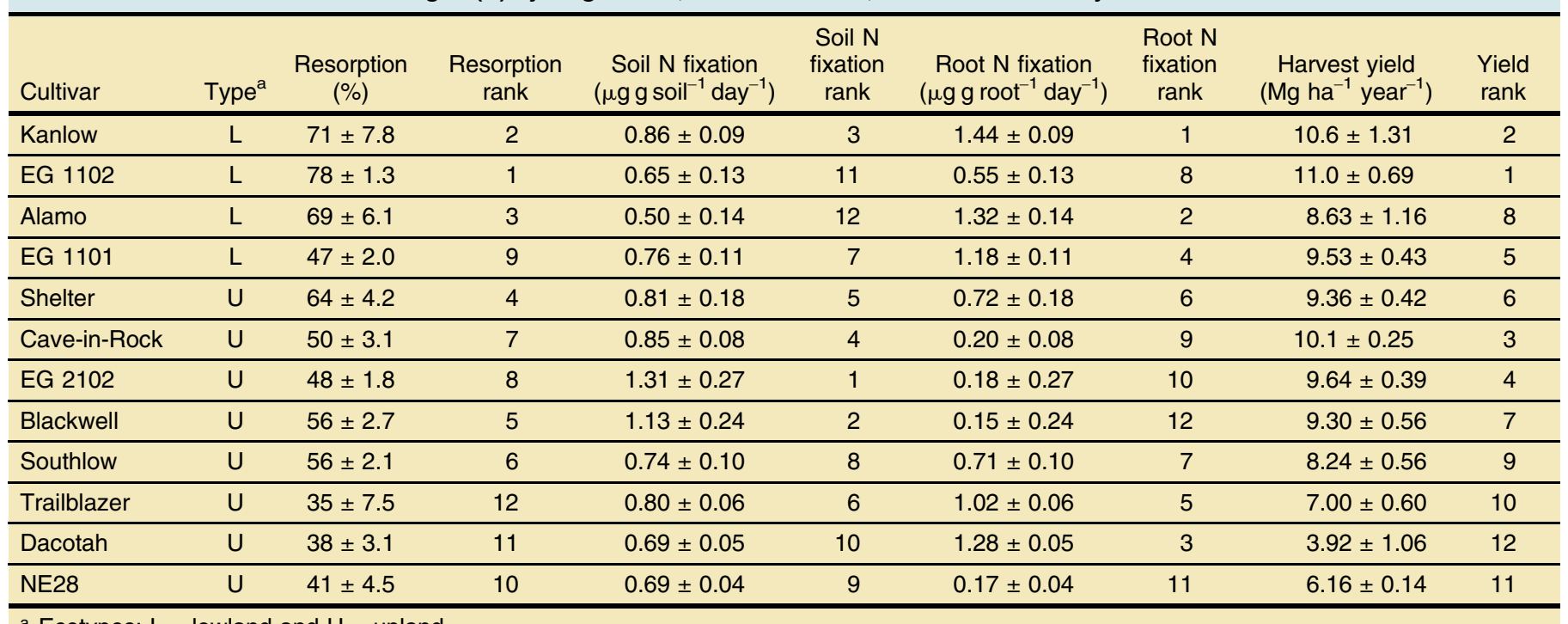

a Ecotypes: $\mathrm{L}=$ lowland and $\mathrm{U}=$ upland. 
Knowles 1965; O'Toole and Knowles 1973; Smercina et al. 2019a). The $\mathrm{C}$ source (i.e., exudate quality) matters, too; $\mathrm{N}$ fixation rates vary with carbohydrate structure (O'Toole and Knowles 1973; Smercina et al. 2019b). Cultivars vary in their contribution to soil C quantity and quality, which can be influenced by root traits; specifically, greater $\mathrm{C}$ exudation rates occur in cultivars with long, thin root systems (Adkins et al. 2016; de Graaff et al. 2014). In our N fixation measurements, we added glucose to the soils and, therefore, may have partially obscured existing cultivar-specific soil $\mathrm{C}$ differences and, thus, weakened cultivar-level differences in $\mathrm{N}$ fixation. Nonetheless, differences in diazotroph community structure may also be a result of soil C differences (Feng et al. 2018; Ouyang et al. 2018). Cultivar-specific switchgrass microbial communities respond differently to ex situ $\mathrm{C}$ inputs (de Graaff et al. 2014); thus, even though labile $\mathrm{C}$ quantity and quality were essentially the same across cultivars in our assays (i.e., glucose), the response to that $\mathrm{C}$ likely varied with a cultivar's distinct soil microbial community (T. C. Ulbrich, M. L. Friesen, S. S. Roley, L. K. Tiemann, and S. E. Evans, unpublished).

Mineralization and nitrification. In contrast to potential $\mathrm{N}$ fixation, switchgrass cultivars exhibited weak cultivar effects on soil $\mathrm{N}$ mineralization and nitrification. Both net $\mathrm{N}$ mineralization and nitrification rates were close to zero, which is generally the case for perennial grass plots at our study site (Millar and Robertson 2015; Roley et al. 2018). Likely potential mechanisms for cultivaror ecotype-effects on mineralization and nitrification include (i) altering microbial C:N ratios (e.g., through litter C:N ratios) (Stark and Norton 2015) and (ii) altering soil N content (e.g., through differential $\mathrm{N}$ uptake rates). Cultivar-specific nitrification inhibition, as occurs in some grasses (Karwat et al. 2018; O'Sullivan et al. 2016), might also play a role but it has not yet been documented for switchgrass. Because we observed no cultivar-specific differences in nitrification rates, nitrification inhibition is similar across cultivars, if it occurs. Both soil $\mathrm{N}$ content and microbial $\mathrm{C}: \mathrm{N}$ ratios are well-known drivers of soil mineralization and nitrification (Dijkstra et al. 2005; Liu et al. 2017; Robertson and Groffman 2015). We did not observe differences in soil $\mathrm{N}$ by cultivar or ecotype but we did observe lower microbial $\mathrm{C}: \mathrm{N}$ ratios in lowland ecotypes (data not shown), which may explain the slightly higher mineralization rates in lowland ecotypes. The weak and low-magnitude effect of ecotype on mineralization suggests, however, that mineralization is not a major driver of cultivar- or ecotype-specific $\mathrm{N}$ acquisition rates.

Temporal variability and $\mathbf{N}$ cycling processes. Our experimental design emphasized number of cultivars rather than temporal frequency but the processes of nitrification, mineralization, and $\mathrm{N}$ fixation all vary seasonally alongside changes in soil moisture, temperature, and N content (Millar and Robertson 2015; Roley et al. 2018). To minimize seasonal effects, we measured the $\mathrm{N}$ cycling processes in the lab under standard temperature and moisture conditions. However, we are unable to control for potential interactions between season and cultivar. Specifically, we surmised that differences among cultivars were due to either differences in the rhizosphere microbiome or in $\mathrm{C}$ exudate quality or quantity (see previous two sections). Root exudate composition varies with plant growth stage (Zhalnina et al. 2018) and, therefore, it's possible that $\mathrm{N}$ process rates changed over time as well, if they are responsive to $\mathrm{C}$ composition. It's not known if root exudate composition varies among switchgrass cultivars but rice root exudate profiles vary by genotype and throughout development (Aulakh et al. 2001). Thus, we offer the caveat that the trends in $\mathrm{N}$ cycling we observed among cultivars may vary through time, leading to cultivar-time interactions if cultivars vary in exudate quantity or quality.

Similarly, $\mathrm{N}$ translocation can vary interannually in grasses as a function of climate (Ren et al. 2018); thus, it's likely that the values we report here are not absolute for these cultivars even at this site. Nonetheless, among-cultivar differences remain valid, particularly given that we observed the same among-cultivar comparisons as Yang et al. (2009).

Cultivar choice for commercial growth. Yield will likely be one of the principal determinants of cultivar choice for commercial growers (Mitchell et al. 2012; Parrish and Fike 2005; Robertson et al. 2017). Yield trends here and elsewhere have identified several high-yielding switchgrass cultivars, and additional breeding is likely to enhance yields further (Casler et al. 2018). Cultivar yields also vary with geographic location (Casler et al. 2007) and, therefore, cultivar choice will favor those that perform well at particular locations. The inclusion of $\mathrm{N}$ efficiency traits could further narrow candidates to those that will require the least $\mathrm{N}$ fertilizer, which is one of the most expensive inputs both economically (Song et al. 2011) and environmentally (Robertson et al. 2017; Ruan et al. 2016). Similar strategies have begun to be used in grain crops such as wheat (Swarbreck et al. 2019; Sylvester-Bradley and Kindred 2009). Our findings suggest that the two ways in which cultivars vary in $\mathrm{N}$ efficiency are through translocation and $\mathrm{N}$ fixation.

Although $\mathrm{N}$ translocation rates vary geographically, amongcultivar and between-ecotype patterns are generally robust to latitudinal and soil differences (Yang and Udvardi 2018). As a result, we expect that the comparisons presented here will be relevant in other geographies. $\mathrm{N}$ fixation rates are variable in space and time (Gupta et al. 2006), and it is unknown how latitude and soil types interact with cultivar identity to affect $\mathrm{N}$ fixation. We expect some cultivar-specific drivers of $\mathrm{N}$ fixation, including energy sources and root traits, to be similar among locations; for example, a cultivar that releases more $\mathrm{C}$ in its root exudates at Location $\mathrm{X}$ will likely also do so at Location Y. Switchgrass microbial community composition varies with geography (Jesus et al. 2016; Liang et al. 2016) but is generally distinct from that of other plant species grown in soil from the same site (Jesus et al. 2016), characterized, in part, by a greater abundance of diazotrophs (Mao et al. 2013). Soil microbial communities beneath individual cultivars will also likely be locally distinct while retaining functional differences. If true, then the patterns reported for $\mathrm{N}$ fixation potentials here should also be robust: upland cultivars (especially EG 2102 and Blackwell) had higher soil $\mathrm{N}$ fixation potential, likely leading to higher soil $\mathrm{N}$ availability, whereas lowland cultivars (especially Kanlow and Alamo) had higher $\mathrm{N}$ translocation rates and root $\mathrm{N}$ fixation potentials, leading to lower plant $\mathrm{N}$ demands of the soil environment.

Are there trade-offs among the cultivars' N-cycling strategies? Or are some cultivars simultaneously stimulating $\mathrm{N}$ fixation and conserving N? It varies. Some cultivars exhibited both efficient $\mathrm{N}$ conservation and efficient $\mathrm{N}$ acquisition strategies. Kanlow, for example, had the highest root $\mathrm{N}$ fixation potential, third-highest soil $\mathrm{N}$ fixation potential, and second-highest $\mathrm{N}$ translocation rates. In contrast, NE28 performed poorly on all metrics of $\mathrm{N}$ efficiency, with the second-lowest $\mathrm{N}$ resorption and root $\mathrm{N}$ fixation potential and ninth-lowest soil $\mathrm{N}$ fixation potential. Other cultivars showed trade-offs; for example, EG 1102 had the highest $\mathrm{N}$ resorption but the second-lowest soil $\mathrm{N}$ fixation potential and the eighth-lowest root $\mathrm{N}$ fixation potential (Table 1).

How do we use observed $\mathrm{N}$ cycling differences to inform agronomic decisions? From an economic and environmental costs perspective, a high-yielding cultivar that does not require fertilizer is preferred, and several cultivars may meet these criteria. At our study site, nearby unfertilized plots of Cave-in-Rock usually attain yields comparable with those of fertilized plots, despite annual harvest that removes substantial amounts of $\mathrm{N}$ in biomass (Roley et al. 2018; Wang et al. 2020). Cave-in-Rock grown in New York and 
Blackwell grown in Oklahoma have also obtained maximum yields without fertilizer (Fike et al. 2017). Cave-in-Rock and Blackwell were middle performers for our $\mathrm{N}$ fixation and $\mathrm{N}$ translocation measures (although Blackwell ranked high for soil $\mathrm{N}$ fixation potential) (Table 1), which suggests that other cultivars, particularly those that foster higher $\mathrm{N}$ fixation rates and resorb more $\mathrm{N}$ such as Kanlow, can also be grown successfully without $\mathrm{N}$ fertilizer.

Cultivar N response appears to vary by site (Fike et al. 2017) and, thus far, lowland $\mathrm{N}$ responses have been mostly tested at lower latitudes; therefore, it remains unknown whether Kanlow would do well without fertilizer at northern sites like ours. We note that Kanlow and Cave-in-Rock had similar modeled responses to $\mathrm{N}$ fertilizer (Lee et al. 2012, 2015) but Kanlow had a stronger response to $\mathrm{N}$ than Cave-in-Rock in Illinois, United States (Revillini et al. 2019).

That cultivars differ substantially in $\mathrm{N}$ conservation and acquisition capacities suggests the likelihood of genetic explanations for these traits. If so, these differences should be exploited by breeders to incorporate traits for $\mathrm{N}$ fixation and translocation efficiency into future high-yielding cultivars.

\section{ACKNOWLEDGMENTS}

We thank I. Schley for help with field and lab work; D. Pennington for establishing the switchgrass plots; D. Pennington, J. Simmons, S. VanderWulp, K. Thelen, and T. Martin for maintaining the plots and measuring yield; and R. Learn for providing valuable statistics advice.

\section{LITERATURE CITED}

Adkins, J., Jastrow, J. D., Morris, G. P., Six, J., and de Graaff, M. A. 2016. Effects of switchgrass cultivars and intraspecific differences in root structure on soil carbon inputs and accumulation. Geoderma 262:147-154.

Aulakh, M. S., Wassmann, R., Bueno, C., Kreuzwieser, J., and Rennenberg, H. 2001. Characterization of root exudates at different growth stages of ten rice (Oryza sativa L.) cultivars. Plant Biol. 3:139-148.

Bahulikar, R. A., Torres-Jerez, I., Worley, E., Craven, K., and Udvardi, M. K. 2014. Diversity of nitrogen-fixing bacteria associated with switchgrass in the native tallgrass prairie of northern Oklahoma. Appl. Environ. Microbiol. 80: 5636-5643.

Bottomley, P. J., and Myrold, D. D. 2015. Biological N inputs. Pages 447-470 in: Soil Microbiology, Ecology, and Biochemistry. E. A. Paul, ed. Academic Press, San Diego, CA, U.S.A.

Brouzes, R., Lasik, J., and Knowles, R. 1969. Effect of organic amendment, water content, and oxygen on incorporation of ${ }^{15} \mathrm{~N}_{2}$ by some agricultural and forest soils. Can. J. Microbiol. 15:899-905.

Bulgarelli, D., Schlaeppi, K., Spaepen, S., van Themaat, E. V. L., and SchulzeLefert, P. 2013. Structure and functions of the bacterial microbiota of plants. Annu. Rev. Plant Biol. 64:807-838.

Burgmann, H., Meier, S., Bunge, M., Widmer, F., and Zeyer, J. 2005. Effects of model root exudates on structure and activity of a soil diazotroph community. Environ. Microbiol. 7:1711-1724.

Casler, M. 2012. Switchgrass breeding, genetics, and genomics. Pages 29-53 in: Switchgrass: A Valuable Biomass Crop for Energy. A. Monti, ed. SpringerVerlag, London, U.K.

Casler, M. D., Vogel, K. P., Lee, D. K., Mitchell, R. B., Adler, P. R., Sulc, R. M., Johnson, K. D., Kallenbach, R. L., Boe, A. R., Mathison, R. D., Cassida, K. A., Min, D. H., Crawford, J., and Moore, K. J. 2018. 30 years of progress toward increased biomass yield of switchgrass and big bluestem. Crop Sci. 58:1242-1254

Casler, M. D., Vogel, K. P., Taliaferro, C. M., Ehlke, N. J., Berdahl, J. D., Brummer, E. C., Kallenbach, R. L., West, C. P., and Mitchell, R. B. 2007. Latitudinal and longitudinal adaptation of switchgrass populations. Crop Sci. 47:2249-2260

Chang, P. C., and Knowles, R. 1965. Non-symbiotic nitrogen fixation in some Quebec soils. Can. J. Microbiol. 11:29-38.

Clark, F. E. 1977. Internal cycling of nitrogen-15 in short grass prairie. Ecology 58:1322-1333.
Crum, J. R., and Collins, H. P. 1995. Soils of the Kellogg Biological Station (KBS). KBS-LTER Special Publication, Zenodo. https://zenodo.org/record/ 2560750

de Graaff, M. A., Jastrow, J. D., Gillette, S., Johns, A., and Wullschleger, S. D. 2014. Differential priming of soil carbon driven by soil depth and root impacts on carbon availability. Soil Biol. Biochem. 69:147-156.

Dijkstra, F. A., Hobbie, S. E., Reich, P. B., and Knops, J. M. H. 2005. Divergent effects of elevated $\mathrm{CO}_{2}, \mathrm{~N}$ fertilization, and plant diversity on soil $\mathrm{C}$ and $\mathrm{N}$ dynamics in a grassland field experiment. Plant Soil 272:41-52.

Dynarski, K. A., and Houlton, B. Z. 2018. Nutrient limitation of terrestrial freeliving nitrogen fixation. New Phytol. 217:1050-1061.

Emery, S. M., Kinnetz, E. R., Bell-Dereske, L., Stahlheber, K. A., Gross, K. L., and Pennington, D. 2018. Low variation in arbuscular mycorrhizal fungal associations and effects on biomass among switchgrass cultivars. Biomass Bioenergy 119:503-508

Feng, M. M., Adams, J. M., Fan, K. K., Shi, Y., Sun, R. B., Wang, D. Z., Guo, X. S., and Chu, H. Y. 2018. Long-term fertilization influences community assembly processes of soil diazotrophs. Soil Biol. Biochem. 126:151-158

Fierer, N., and Jackson, R. B. 2006. The diversity and biogeography of soil bacterial communities. Proc. Natl. Acad. Sci. U.S.A. 103:626-631.

Fike, J. H., Pease, J. W., Owens, V. N., Farris, R. L., Hansen, J. L., Heaton, E. A., Hong, C. O., Mayton, H. S., Mitchell, R. B., and Viands, D. R. 2017. Switchgrass nitrogen response and estimated production costs on diverse sites. Glob. Change Biol. Bioenergy 9:1526-1542.

Gupta, V. V. S. R., Kroker, S. J., Hicks, M., Davoren, C. W., Descheemaeker, K., and Llewellyn, R. 2014. Nitrogen cycling in summer active perennial grass systems in South Australia: Non-symbiotic nitrogen fixation. Crop Pasture Sci. 65:1044-1056.

Gupta, V. V. S. R., Roper, M. M., and Roget, D. K. 2006. Potential for nonsymbiotic N2-fixation in different agroecological zones of southern Australia. Aust. J. Soil Res. 44:343-354.

Heckathorn, S. A., and Delucia, E. H. 1996. Retranslocation of shoot nitrogen to rhizomes and roots in prairie grasses may limit loss of $\mathrm{N}$ to grazing and fire during drought. Funct. Ecol. 10:396-400.

Hsu, S. F., and Buckley, D. H. 2009. Evidence for the functional significance of diazotroph community structure in soil. ISME J. 3:124-136.

Jach-Smith, L. C., and Jackson, R. D. 2015. Nitrogen conservation decreases with fertilizer addition in two perennial grass cropping systems for bioenergy. Agric. Ecosyst. Environ. 204:62-71.

Jarrell, W., Armstrong, D., Grigal, D., Kelly, E., Monger, H., and Wedin, D. 1999. Soil water and temperature status. Pages 55-73 in: Standard Soil Methods for Long-Term Ecological Research. G. P. Robertson, D. C. Coleman, C. S. Bledsoe, and P. Sollins, eds. Oxford University Press, New York, NY, U.S.A.

Jesus, E. D., Liang, C., Quensen, J. F., Susilawati, E., Jackson, R. D., Balser, T. C., and Tiedje, J. M. 2016. Influence of corn, switchgrass, and prairie cropping systems on soil microbial communities in the upper Midwest of the United States. Glob. Change Biol. Bioenergy 8:481-494.

Jovel, J., Patterson, J., Wang, W., Hotte, N., O’Keefe, S., Mitchel, T., Perry, T., Kao, D., Mason, A. L., Madsen, K. L., and Wong, G. K.-S. 2016.

Characterization of the gut microbiome using $16 \mathrm{~S}$ or shotgun metagenomics. Front. Microbiol. 7:459.

Karwat, H., Egenolf, K., Nuñez, J., Rao, I., Rasche, F., Arango, J., Moreta, D., Arevalo, A., and Cadisch, G. 2018. Low ${ }^{15} \mathrm{~N}$ natural abundance in shoot tissue of Brachiaria humidicola is an indicator of reduced $\mathrm{N}$ losses due to biological nitrification inhibition (BNI). Front. Microbiol. 9:2383.

KBS LTER Data Catalog. 2019. LTER Weather Station-Daily precip and air temp. Michigan State University, W. K. Kellogg Biological Station. https:// lter.kbs.msu.edu/datatables/7

Killingbeck, K. T. 1996. Nutrients in senesced leaves: Keys to the search for potential resorption and resorption proficiency. Ecology 77:1716-1727.

Langille, M. G. I., Zaneveld, J., Caporaso, J. G., McDonald, D., Knights, D., Reyes, J. A., Clemente, J. C., Burkepile, D. E., Vega Thurber, R. L., Knight, R., Beiko, R. G., and Huttenhower, C. 2013. Predictive functional profiling of microbial communities using $16 \mathrm{~S}$ rRNA marker gene sequences. Nat. Biotechnol. 31:814-821.

LeBauer, D. S., and Treseder, K. K. 2008. Nitrogen limitation of net primary productivity in terrestrial ecosystems is globally distributed. Ecology 89: 371-379.

Lee, J., Pedroso, G., Linquist, B. A., Putnam, D., van Kessel, C., and Six, J. 2012. Simulating switchgrass biomass production across ecoregions using the DAYCENT model. GCB Bioenergy 4:521-533. 
Lee, J., Pedroso, G., van Kessel, C., and Six, J. 2015. Potential regional productivity and greenhouse gas emissions of fertilized and irrigated switchgrass in a Mediterranean climate. Agric. Ecosyst. Environ. 212: 64-74.

Liang, C., Jesus, E. D., Duncan, D. S., Quensen, J. F., Jackson, R. D., Balser, T. C., and Tiedje, J. M. 2016. Switchgrass rhizospheres stimulate microbial biomass but deplete microbial necromass in agricultural soils of the upper Midwest, USA. Soil Biol. Biochem. 94:173-180.

Lindsay, E. A., Colloff, M. J., Gibb, N. L., and Wakelin, S. A. 2010. The abundance of microbial functional genes in grassy woodlands is influenced more by soil nutrient enrichment than by recent weed invasion or livestock exclusion. Appl. Environ. Microbiol. 76:5547-5555.

Liu, X.-J., van Groenigen, K. J., Dijkstra, F. A., and Hungate, B. A. 2017 Increased plant uptake of native soil nitrogen following fertilizer addition-Not a priming effect? Appl. Soil Ecol. 114:105-110.

Lowry, D. B., Behrman, K. D., Grabowski, P., Morris, G. P., Kiniry, J. R., and Juenger, T. E. 2014. Adaptations between ecotypes and along environmental gradients in Panicum virgatum. Am. Nat. 183:682-692.

Luehmann, M. D., Peter, B. G., Connallon, C. B., Schaetzl, R. J., Smidt, S. J., Liu, W., Kincare, K. A., Walkowiak, T. A., Thorlund, E., and Holler, M. S. 2016. Loamy, two-storied soils on the outwash plains of southwestern lower Michigan: Pedoturbation of loess with the underlying sand. Ann. Assoc. Am. Geogr. 106:551-572.

Mao, Y., Yannarell, A. C., Davis, S. C., and Mackie, R. I. 2013. Impact of different bioenergy crops on $\mathrm{N}$-cycling bacterial and archaeal communities in soil. Environ. Microbiol. 15:928-942.

Meier, I. C., Finzi, A. C., and Phillips, R. P. 2017. Root exudates increase N availability by stimulating microbial turnover of fast-cycling $\mathrm{N}$ pools. Soil Biol. Biochem. 106:119-128.

Michigan State Climatologist's Office. 2019. Gull Lake (3504). Michigan State University. https://climate.geo.msu.edu/climate_mi/stations/3504/

Millar, N., and Robertson, G. P. 2015. Nitrogen transfers and transformations in row-crop ecosystems. Pages 213-251 in: The Ecology of Agricultural Landscapes: Long-Term Research on the Path to Sustainability. S. K. Hamilton, J. E. Doll, and G. P. Robertson, eds. Oxford University Press, New York, NY, U.S.A.

Mitchell, R., Vogel, K. P., and Uden, D. R. 2012. The feasibility of switchgrass for biofuel production. Biofuels 3:47-59.

Morris, D. R., Zuberer, D. A., and Weaver, R. W. 1985. Nitrogen fixation by intact grass-soil cores using ${ }^{15} \mathrm{~N}_{2}$ and acetylene reduction. Soil Biol. Biochem. 17:87-91.

Murphy, C. J., Baggs, E. M., Morley, N., Wall, D. P., and Paterson, E. 2015. Rhizosphere priming can promote mobilisation of N-rich compounds from soil organic matter. Soil Biol. Biochem. 81:236-243.

O’Sullivan, C. A., Fillery, I. R. P., Roper, M. M., and Richards, R. A. 2016. Identification of several wheat landraces with biological nitrification inhibition capacity. Plant Soil 404:61-74.

O'Toole, P., and Knowles, R. 1973. Efficiency of acetylene reduction (nitrogen fixation) in soil: Effect of type and concentration of available carbohydrate. Soil Biol. Biochem. 5:789-797.

Ouyang, Y., Evans, S. E., Friesen, M. L., and Tiemann, L. K. 2018. Effect of nitrogen fertilization on the abundance of nitrogen cycling genes in agricultural soils: A meta-analysis of field studies. Soil Biol. Biochem. 127:71-78.

Parrish, D. J., and Fike, J. H. 2005. The biology and agronomy of switchgrass for biofuels. Crit. Rev. Plant Sci. 24:423-459.

Perakis, S. S., and Sinkhorn, E. R. 2011. Biogeochemistry of a temperate forest nitrogen gradient. Ecology 92:1481-1491.

R Core Team. 2017. R: A Language and Environment for Statistical Computing. http://www.R-project.org/

Reed, S. C., Townsend, A. R., Cleveland, C. C., and Nemergut, D. R. 2010 Microbial community shifts influence patterns in tropical forest nitrogen fixation. Oecologia 164:521-531.

Regus, J. U., Wendlandt, C. E., Bantay, R. M., Gano-Cohen, K. A., Gleason, N. J., Hollowell, A. C., O'Neill, M. R., Shahin, K. K., and Sachs, J. L. 2017. Nitrogen deposition decreases the benefits of symbiosis in a native legume. Plant Soil 414:159-170.

Reinhold-Hurek, B., Bünger, W., Burbano, C. S., Sabale, M., and Hurek, T. 2015. Roots shaping their microbiome: Global hotspots for microbial activity. Annu. Rev. Phytopathol. 53:403-424.

Ren, H. Y., Kang, J., Yuan, Z. Y., Xu, Z. W., and Han, G. D. 2018. Responses of nutrient resorption to warming and nitrogen fertilization in contrasting wet and dry years in a desert grassland. Plant Soil 432:65-73.

Revillini, D., Wilson, G. W. T., Miller, R. M., Lancione, R., and Johnson, N. C. 2019. Plant diversity and fertilizer management shape the belowground microbiome of native grass bioenergy feedstocks. Front. Plant Sci. 10: 1018.

Robertson, G. P., and Groffman, P. M. 2015. Nitrogen transformations. Pages 421-446 in: Soil Microbiology, Ecology, and Biochemistry, 4th ed. E. A. Paul, ed. Academic Press, New York, NY, U.S.A.

Robertson, G. P., Hamilton, S. K., Barham, B. L., Dale, B. E., Izaurralde, R. C., Jackson, R. D., Landis, D. A., Swinton, S. M., Thelen, K. D., and Tiedje, J. M. 2017. Cellulosic biofuel contributions to a sustainable energy future: Choices and outcomes. Science 356:eaal2324.

Robertson, G. P., Wedin, D., Groffman, P. M., Blair, J. M., Holland, E. A., Nadelhoffer, K., and Harris, D. 1999. Soil carbon and nitrogen availability: Nitrogen mineralization, nitrification, and soil respiration potentials. Pages 258-271 in: Standard Soil Methods for Long-Term Ecological Research. G. P. Robertson, D. C. Coleman, C. S. Bledsoe, and P. Sollins, eds. Oxford University Press, New York, NY, U.S.A..

Rocca, J. D., Hall, E. K., Lennon, J. T., Evans, S. E., Waldrop, M. P., Cotner, J. B., Nemergut, D. R., Graham, E. B., and Wallenstein, M. D. 2015. Relationships between protein-encoding gene abundance and corresponding process are commonly assumed yet rarely observed. ISME J. 9:1693-1699.

Rodrigues, R. R., Moon, J., Zhao, B., and Williams, M. A. 2017. Microbial communities and diazotrophic activity differ in the root-zone of Alamo and Dacotah switchgrass feedstocks. Glob. Change Biol. Bioenergy 9: 1057-1070.

Roley, S. S., Duncan, D. S., Liang, D., Garoutte, A., Jackson, R. D., Tiedje, J. M., and Robertson, G. P. 2018. Associative nitrogen fixation (ANF) in switchgrass (Panicum virgatum) across a nitrogen input gradient. PLoS One 13:e0197320.

Roley, S. S., Xue, C., Hamilton, S. K., Tiedje, J. M., and Robertson, G. P. 2019. Isotopic evidence for episodic nitrogen fixation in switchgrass (Panicum virgatum L.). Soil Biol. Biochem. 129:90-98.

Roosendaal, D., Stewart, C. E., Denef, K., Follett, R. E., Pruessner, E., Comas, L. H., Varvel, G. E., Saathoff, A., Palmer, N., Sarath, G., Jin, V. L., Schmer, M., and Soundararajan, M. 2016. Switchgrass ecotypes alter microbial contribution to deep-soil C. Soil (Gottingen) 2:185-197.

Ruan, L. L., Bhardwaj, A. K., Hamilton, S. K., and Robertson, G. P. 2016. Nitrogen fertilization challenges the climate benefit of cellulosic biofuels. Environ. Res. Lett. 11:064007.

Schroeder-Moreno, M. S., Greaver, T. L., Wang, S. X., Hu, S. J., and Rufty, T. W. 2012. Mycorrhizal-mediated nitrogen acquisition in switchgrass under elevated temperatures and $\mathrm{N}$ enrichment. Glob. Change Biol. Bioenergy 4: 266-276.

Singer, E., Bonnette, J., Kenaley, S. C., Woyke, T., and Juenger, T. E. 2019. Plant compartment and genetic variation drive microbiome composition in switchgrass roots. Environ. Microbiol. Rep. 11:185-195.

Smercina, D. N., Evans, S. E., Friesen, M. L., and Tiemann, L. K. 2019a. To fix or not to fix: Controls on free-living nitrogen fixation in the rhizosphere. Appl. Environ. Microbiol. 85:e02546-18.

Smercina, D. N., Evans, S. E., Friesen, M. L., and Tiemann, L. K. 2019b. Optimization of the ${ }^{15} \mathrm{~N}_{2}$ incorporation and acetylene reduction methods for free-living nitrogen fixation. Plant Soil 445:595-611.

Song, F., Zhao, J., and Swinton, S. M. 2011. Switching to perennial energy crops under uncertainty and costly reversibility. Am. J. Agric. Econ. 93:768-783.

Stahlheber, K. A., Lindquist, J., Drogosh, P. D., Pennington, D., and Gross, K. L. Predicting productivity: A trait-based analysis of variability in biomass yield among switchgrass feedstock cultivars. Agric. Ecosyst. Environ. In press.

Stark, J. M., and Norton, J. M. 2015. The invasive annual cheatgrass increases nitrogen availability in 24-year-old replicated field plots. Oecologia 177: 799-809.

Swarbreck, S. M., Wang, M., Wang, Y., Kindred, D. R., Sylvester-Bradley, R., Shi, W., Varinderpal-Singh, Bentley, A. R., and Griffiths, H. 2019. A roadmap for lowering crop nitrogen requirement. Trends Plant Sci. 24: 892-904.

Sylvester-Bradley, R., and Kindred, D. R. 2009. Analysing nitrogen responses of cereals to prioritize routes to the improvement of nitrogen use efficiency. J. Exp. Bot. 60:1939-1951.

Tjepkema, J. 1975. Nitrogenase activity in the rhizosphere of Panicum virgatum. Soil Biol. Biochem. 7:179-180.

Vergutz, L., Manzoni, S., Porporato, A., Novais, R. F., and Jackson, R. B. 2012. Global resorption efficiencies and concentrations of carbon and nutrients in leaves of terrestrial plants. Ecol. Monogr. 82:205-220.

Wang, Q., Wang, J. L., Li, Y. Z., Chen, D. W., Ao, J. H., Zhou, W. L., Shen, D. C., Li, Q. W., Huang, Z. R., and Jiang, Y. 2018. Influence of nitrogen and phosphorus additions on $\mathrm{N}_{2}$-fixation activity, abundance, and composition of 
diazotrophic communities in a Chinese fir plantation. Sci. Total Environ. 619-620:1530-1537.

Wang, S., Sanford, G. R., Robertson, G. P., Jackson, R. D., and Thelen, K. D. 2020. Perennial bioenergy crop yield and quality response to nitrogen fertilization. BioEnergy Res. 13:157-166.

Weese, D. J., Heath, K. D., Dentinger, B. T. M., and Lau, J. A. 2015. Long-term nitrogen addition causes the evolution of less-cooperative mutualists. Evolution 69:631-642.

Yang, J. D., and Udvardi, M. 2018. Senescence and nitrogen use efficiency in perennial grasses for forage and biofuel production. J. Exp. Bot. 69: $855-865$.
Yang, J. D., Worley, E., Wang, M. Y., Lahner, B., Salt, D. E., Saha, M., and Udvardi, M. 2009. Natural variation for nutrient use and remobilization efficiencies in switchgrass. BioEnergy Res. 2:257-266.

Yu, P., and Hochholdinger, F. 2018. The role of host genetic signatures on root-microbe interactions in the rhizosphere and endospheres. Front. Plant Sci. 9:1896.

Zhalnina, K., Louie, K. B., Hao, Z., Mansoori, N., da Rocha, U. N., Shi, S., Cho, H., Karaoz, U., Loqué, D., Bowen, B. P., Firestone, M. K., Northen, T. R., and Brodie, E. L. 2018. Dynamic root exudate chemistry and microbial substrate preferences drive patterns in rhizosphere microbial community assembly. Nat. Microbiol. 3:470-480. 